\title{
I Never Knew a Librarian Did That! Exploring How Faculty and Librarian Relationships Support Meaningful \\ Collaboration
}

Kathleen Colantonio-Yurko

Peter Kalenda

Kathleen Olmstead

Logan Rath

Allison Wright

SUNY Brockport

Abstract: This paper examines the relationships that developed over a 10+ year span at a comprehensive college in upstate New York. When the library was reorganized into a generalist model of library support, the faculty members felt unsupported. The paper explains the origin of the department-wide collaboration and then uses reflections to analyze ways in which the relationship with a liaison librarian support the faculty members work. Specific themes include overcoming library anxiety, online teaching support, and scholarship support with suggestions for librarian practice.

Keywords: models of library support, library anxiety, scholarship, online teaching, collaboration,

relationships, faculty

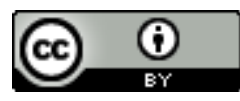

This is an Open Access article distributed under the terms of the Creative Commons Attribution 4.0 International License (http://creativecommons.org/licenses/by/4.0), which permits unrestricted use, distribution, and reproduction in any medium, provided the original work is properly cited.

Journal of New Librarianship, 5(2020) pp. 25-44 10.21173/newlibs/9/2 
In popular media librarians are represented in a multitude of ways. The hunched over woman hissing "shh" at chattering teenagers, a socially awkward book worm, or even in the T.V. show Parks and Recreation-as evil and abusive. For the most part, the authors' interactions with academic and school librarians have been mixed, until they began to collaborate with their librarian. If one were to poll the authors of this article, they would suggest that librarians save classes, students, and research papers from complete despair. Unfortunately, that is not always the case.

In this article, four education professors share their collaborations with their librarian. The authors of this paper include Dr. Kate Colantonio-Yurko and Dr. Kathy Olmstead who both specialize in literacy education, Dr. Peter Kalenda who specializes in science education methods, Professor Allison Wright who specializes in elementary social studies education methods, and their librarian, Mr. Logan Rath. In this article we detail how one librarian managed to enrich our teaching and research practices. We begin by sharing our inspiration for this article, reviewing the importance of collaborative relationships between professors and librarians, and providing a history of our partnerships with our librarian. After a brief introduction of our methodological approach, autoethnography, we will explore different ways that Logan developed relationships with the professors to: 1) overcome anxiety about using the library; 2) provide online teaching support; and 3) support scholarship. Lastly, we share our autoethnographic analysis and resulting collaborative model in the hopes that other librarians have the chance to be as impactful with their faculty peers.

\section{Shifting Models of Librarian Support}

Research has shown the many benefits of utilizing a liaison-based library model. Johnson, McCord, \& Walter (2004) detail the history of liaison-based models, noting that librarians are now often required to collaborate with faculty members in instruction as opposed to simply developing 
appropriate collections. Corrall (2014) provides a current account of how research libraries are reorganizing to emphasize the collaboration between scholars and librarians while also giving a summary of research related to models of library organization. Lastly, Hoodless and Pinfield (2018) describe changes that are happening in the UK where librarians are shifting from subject specialists (one librarian that meets all needs of faculty in that subject) to functional specialists (librarians that specialize in one function of librarianship such as instruction). Libraries with a functional specialist approach would require that faculty members work with a different librarian for each type of library task at hand. Interestingly, through their research, Hoodless and Pinfield found that the relationships with academic departments remained an important aspect to any type of organizational model, and that all of the libraries studied retained some aspect of a subject-specific relationship within the bounds of a specific function such as library instruction. So, the research provides some debate as to the most beneficial model of librarian organization.

In 2018, our institution shifted to a functional model, away from a liaison-based library instruction model that valued long-term relationships and aligned librarian expertise with departments. Unlike the findings of Hoodless and Pinfield (2018), subject-specific relationships were not kept with regard to library instruction. For years our Education department worked to build a rich liaison-based model. The new functional model assigned a random librarian to each request for library instruction, solely based on availability; often requiring faculty members to work with a different librarian who was unfamiliar with their needs every time they had a library need. The challenges we faced with this change inspired us to reflect on and write about our faculty-librarian partnerships. 


\section{The Importance of Collaborative Relationships with Librarians}

The focus of our work addresses how professionally fruitful relationships can grow from sustained and nurtured faculty and librarian collaboration-which is supported by ample research in the field. For instance, Kelly (2019) analyzed a large data set to find that "perceived librarian contact ( $p$ $<.001)$ and faculty goals $(p<.001)$ were both significant predictors of faculty perceptions of librarians' contributions to student learning" (p. 231). Kelly's work, as well as the work of other qualitative researchers, examines the role of the librarian and faculty perceptions of those roles through the use of surveys (Bury, 2011; Cassidy \& Hendrickson, 2013; Douglas \& Rabinowitz, 2016; Meredith \& Mussell, 2014). Overall the studies found that librarians are seen as important in providing information literacy instruction as well as providing a personal connection to the library. While these studies describe effective collaborations, they do not describe the benefits of the personal relationships that have been built and they lack the "thick description" that is essential to highlighting the voices of the faculty (Geertz, 1973).

Some previous work has been done to extoll the benefits of collaboration within our specific department. Logan has published with multiple members of the department in the past. In the latter paper, the authors identified specific facets of what made their collaboration work and how their process could be adapted (Rath \& Cimbricz, 2015). A later analysis examined student responses in a deeply embedded librarian experience (Rath \& Wright, 2018). This paper seeks to add to the body of knowledge that is currently lacking regarding faculty voices and perceptions of collaborative relationships with librarians. We argue that our success was more likely due to our relationships, than to our discrete skill sets and content expertise. 


\section{History of Our Professor-Librarian Partnership}

The positive impacts of having a librarian work so closely with a department are far reaching and deeply felt by the faculty in the department as well as its students. In higher education, collaboration is often limited to librarians providing a general understanding of what supports are available to students throughout the college. Professors then direct students to seek guidance and support from whomever is deemed the best fit for their immediate needs. This is sufficient since the students may ultimately connect with colleagues who can assist them with skills and knowledge that will support their scholarly pursuits. However, it still creates a disconnect between the professionals themselves and leaves the students feeling as though they have to navigate between two people who are aware of each other, but not working closely enough together to truly understand the students' shared goals.

Allison felt this disconnection when working towards earning her degree. Typically, there was a day that was designated as "library day." Allison and her classmates visited the library while the librarian shared with the class the available resources. The sessions always ended by inviting students to contact the librarians with questions, but many students never did. There were many times when professors did not even attend these sessions, so it was hard to truly understand the value of each session as more than just "informational." This perception followed Allison when she became an education professor and framed her approach to the role library instruction would play with her students. After her first scheduled "library day," her eyes were opened to the vast potential library instruction could actually be to her students, and to herself. 


\section{Origin Story: Allison's Reflection}

When I first started my career in higher education I made a commitment to ensure my students were connected with resources at the university library I knew would help them to be more successful when completing my course requirements. Specifically, our library had a section designated for students seeking teacher certification that had a number of elementary/ adolescent resources available for students to borrow as they prepared and implemented meaningful lesson plans with their own students in their field placements. I reflected on my own time as an undergraduate and graduate student in the same university and how I was unaware that this section of the library even existed. I contacted the library to set a time for one of the librarians to take my students and me on a tour as well as lead an instruction session. In all honesty, my expectations leading into that meeting were that the students would gain exposure to library supports, and, hopefully, take the initiative to use them when needed. I left that first library instruction session with far more than I had ever expected. I left with a collaboration that had just begun to take shape, and would continue to evolve in meaningful ways over the course of 10 years. Unwittingly, I had stumbled upon what I had never expected, and as it turned out, was the greatest resource the library had to offer... a librarian whose top priority went above and beyond simply providing our students with exposure to library supports.

When the time came the next semester to get my course schedule set I received an email from the librarian I had worked with the previous semester asking me if I'd like to have a meeting to discuss the session and what we might do to improve upon what we had done. I agreed, although at the time I was working under the assumption that there was a limit as to what I could expect. I showed up to the meeting with a brief list of ideas that were based on my preconceptions, and was absolutely shocked that he had a substantial list of potential directions we could take the session depending on what I was hoping my students would gain from the experience. He had researched my course objectives and began to share ways in which he felt his areas of expertise could support my students' success.

Specifically, my course was established to scaffold students as they learned how to prepare for and implement meaningful social science lesson plans - from building their own content knowledge of social science concepts to translating that knowledge into creating developmentally appropriate lesson plans to teach to their elementary level students. This required specific research skills for each assignment. To begin with the students needed guidance as to how to research and evaluate a variety of sources meant to build their own adult content knowledge of the topic they would eventually teach to their elementary students. As the assignments shifted towards focusing on the creation of lesson plans the research needs also shifted and required the students to research and evaluate resources for use with elementary students. Logan was the first to suggest that we not only have one library teaching session during the semester, but rather, have two distinct library teaching sessions so he could tailor his instruction to the unique skills and knowledge necessary for each assignment. At first, I felt as though this was asking too much. After all, I knew he had more 
responsibilities than preparing for my class. But he quickly put me at ease and told me his job was to support faculty and student success, and that's exactly what he did. My students not only had a clear understanding of expectations from my assignment outlines - they also had a clear understanding of the skills needed to meet my expectations from Logan.

As the semesters went on my colleague invested himself in learning more and more about my content and course requirements. We moved to where we co-taught side-by-side, with both of us chiming in when necessary to address student questions with our specific areas of expertise. The students not only felt more confident when approaching the completion of their assignments, they also formed meaningful relationships with Logan and knew he was a person they could go to for support. This led to greater levels of success not only when completing requirements for my course, but when they needed support in other courses as well.

An unforeseen benefit of the collaboration between the Allison and Logan was the fact that

their work together was so successful that other faculty in her department took notice and began seeking out Logan for help with their own classes and professional pursuits. Eventually, courses in our programs were mapped so that students would receive meaningful library support at the right moments throughout their two-year program. While Allison would like to say she is the one who started us all on this amazing pathway she knows all the credit goes to her colleague who was fully committed to ensuring he did everything he possibly could to support the success of the students and faculty at our college.

\section{Autoethnography as a Qualitative Method}

Autoethnography has recently flourished as a qualitative method, privileging the personalized voices of the autoethnographers as data to represent their lived experiences (Wall, 2016). While this method includes rich narrative, autoethnography transcends storytelling to engage in leading us to richer understandings through "cultural analysis and interpretation” (Chang, 2008, p.43). Autoethnography emerged as an approach to research in the 1980 s as many scholars came to acknowledge the limitations of so-called scientific truths which were actually informed by the 
researcher's lens (Ellis, Adams \& Bochner, 2011). Autoethnographic approaches actually serve to embrace the researcher's lens- relying upon the researchers' experiences to inform the research, which is then presented in the form of an accessible text (Ellis, Adams \& Bochner, 2011). For this paper, we lean into evocative autoethnography which incorporates story and emotional experiences into the research and writing, as opposed to analytic autoethnography which seeks to produce theoretical explanations (Adams, Holman-Jones \& Ellis, 2015).

We, as members of the College community who have partnered with a teaching librarian, not only provide analysis of the social practices intertwined in our work with our campus library, but we have also come together to "try to open hearts and minds through stories" (Ellis, 2019, p. 374). As noted previously, in this paper we draw on autoethnographic methods to analyze and explore experiences working with our Education Librarian and we are not alone in this. Deitering (2017) provides an explanation of why autoethnography is an appropriate approach to analyze these lived experiences. She asserts that autoethnography is appropriate in the library context because

"librarianship has a longstanding commitment to the particular, the local, and the specific. As a profession, we clearly value stories-preserving, sharing, and discovering them-and we are committed to helping people create their own.... Personal, reflexive, story-based methods like autoethnography align with these values and also build on a culture of reflective learning and reflective practice that is already strongly influential within academic librarianship." (Deitering, 2017, p. 8)

Researchers like Anderson and Fourie (2015), Fister (2017), and Guzik (2013) have also successfully employed autoethnographic approaches in library and information science contexts. Thus, along with these researchers, we add our voices to this work and share our reflections, at times imbued with emotion, to further explore the complexity of librarian and faculty partnerships. 


\section{Three Reflections on the Power of Librarian Relationships}

In exploring Logan's relationships with faculty, we share three faculty reflections of our collaborative work with him - organized by the following themes: 1) overcoming library anxiety; 2) library relationships and online support; and 3) library relationships support scholarship.

\section{Reflection 1: Overcoming Library Anxiety}

One of the most important aspects of our collective work with our librarian is the relationships he has formed with faculty and students. However, this has not always been a valued trait of all librarians. In his traditional 1962 description of a librarian, college librarian Lowell Robinson suggests that the librarian's "book knowledge and mechanical library skills" are the most important qualities necessary to fortify the librarian's roles of "teaching, administration, and guidance" (p.72). It seems in Robinson's view, the main goal of the teaching librarian was the freshman library orientation, effectively accomplished in one class period with library handouts as artifacts demonstrating the proficient librarian's support. This type of library instruction is inline with Knapp's model of library instruction, which at the time was cutting edge for the field, but was not integrated into courses. Knapp's approach was eventually eclipsed by Farber's course-integrated model, favoring "one-shot" instruction which then shifted to the concept of information literacy as it is known today (Grassian \& Kaplowitz, 2009).

Despite the advances in the field of information literacy, more than half a century later Kathy found little about the role of the librarian had changed while working on her dissertation study of family literacy. Her interactions with the university's librarians were uncomfortable and nervewracking. As an older student, she was often embarrassed to ask for assistance and found the 
assistance she was given insufficient to meet her needs (e.g. a handout, in her case a bookmark with

library search procedures). Kathy's doctoral library experience is described in her reflection below:

As a student who first learned to do research by bringing numerous rounds of journal request slips (along with a bagful of dimes) down to the desolate library basement, I, clearly was not, a digital native. The extinction of the journal slip was a shocking doctoral revelation; digitization was responsible for clearing away hazardous library basements across the country. Along with this purge, came the need for students like me to negotiate the new and foreign online systems for researching. While I could search from my home computer, I could often waste a precious hour just gaining access to my library account. Indeed, if I was lucky enough to be able to log in, the sea of journals was an overwhelming tsunami sucking my time away. How to narrow my search? Which articles were most appropriate? What to do with 2,500 hits on the topic of "early literacy"? And perhaps worst of all, how to cite it all in APA format? Somehow, I managed to complete my dissertation, but I hated my literature review, hated asking for help and not surprisingly, I hated the library. -Kathy, Reflection \#1

SeyyedHosseini, Khosravi \& BasirianJahromi (2014) label what Kathy experienced as "library

anxiety" - the nervousness, discomfort and sometimes even paralysis which they found to be problematic for many library users (p. 2). Jiao and Onwuegbuzie (1999) provide more description, noting the term was first coined in Mellon's (1968) grounded theory study yet is still prevalent today. Kathy's experience is also in line with McAfee's (2018) study that proposed shame as a major reason for anxiety with use of the library. Researchers like SeyyedHosseini, Khosravi \& Basirian Jahromi (2014) suggest a variety of instructional models to reduce library anxiety. However, we suggest the fostering of positive personalized relationshipscan also be a mitigating factor, perhaps more effective at decreasing library anxiety than changing up methods of information literacy and information technology instruction. This is illustrated through Kathy's reflection below regarding the power of personalized relationships.

I met our librarian in the first weeks of my job as a new Assistant Professor of Literacy. He explained the support he would provide for students in my Master's thesis class during a meeting at a colleague's office. Surprised that a librarian would "make house calls," and amazed by the array of supports he could provide (even training for managing online citations), 
already I was at ease and wished that my previous university had employed a teaching librarian dedicated to working with individual departments to support their work with students, their research, scholarship, and even technology. It was most effective to have someone who knows me, my students and my courses and who could differentiate support according to my "unique constellation" of strengths, needs, interests and teaching style (Simon \& Campano, 2013, p.23).

Even now, years later, I can't help thinking that I would have had a totally different experience writing my dissertation had I felt my needs as an older student were understood, if I had a safe space to ask questions and if I had received non-judgmental, one-to- one support, as I had with our personalized librarian. Instead of an irritated sigh or eye roll from a random librarian each time I entered the library, my requests with Logan were met with "You are not a bother; this is my job." and even an unexpected "Searching for this obscure citation is FUN for me!" Sadly, I was one of only three dissertation completers in a doctoral cohort of more than twelve. How might the number of completers have changed with personalized relationships with a librarian? Instead of a source of anxiety, our librarian has demonstrated that the library could be a place with people who "show they care" (Smith, 2002, p. 18). -Kathy, Reflection \#2

Indeed, faculty support is only one component of effective librarian collaboration on campus.

Personalized relationships considering the needs, learning styles and library comfort levels of individual students is also beneficial. Mezick (2015) suggests that librarians who have this connection with students, and provide both "academic and social support" can have an impact on student academic achievement, student persistence and not surprisingly, improve student retention in higher education (p. 32).

\section{Reflection 2: Library Relationships and Online Teaching Support}

When Peter started working at Brockport, he was given hybrid and fully online courses to

teach. Although he had some experience with teaching in a hybrid setting in P-12 classrooms, he had

never run full courses at the college level in these platforms.

I knew I needed support to teach online and my husband, Logan, shared that this is an area he can help with. I thought he was just being overly supportive at first because my history working with librarians had led me to believe that they didn't do much to support students and professors. For example, while working on my dissertation research I requested an article from my college library and my Education Librarian told me that the best way to get my niche article requests was by subscribing to these journals myself. An annual subscription was only $\$ 60$ a 
year for me, and much more per article for the library. That had ended my desire to collaborate with librarians for the remainder of my dissertation writing.

I learned quickly that Logan was a major support in the Education Department with helping professors gain access to resources that allowed them to effectively teach in face-to-face and online environments. Over 10 years he had built trusting relationships with professors that allowed them to feel safe and admit they did not understand technology. Nearly all hybrid and fully online professors had already added him to their online courses to assist with various needs. -Peter, Reflection \#1

Peter struggled to find ways to allow his hybrid students to collaborate in writing unit plans in an online space beyond traditional discussion boards, Wikis, and shared Google Docs spaces. Logan suggested the use of a tool called VoiceThread (https://www.voicethread.com). With this tool, learners could present their work with slides and videos, and then peers could provide video feedback. Adding this tool to the course shifted online learning, as described in Peter's second reflection:

VoiceThread was the perfect tool to allow for online collaboration that was more personal than just writing back and forth. I was not sure about how to teach my students how to use this technology, so I asked Logan if he could assist. He came to the classroom and all the students already knew him by name. I learned that Logan came to classes with these students each semester for 2 years. This allowed him to also build relationships with students and scaffold their learning. Using his knowledge of their schema, he was able to quickly teach them how to use this software with ease. -Peter, Reflection \#2

Trying to teach the use of software, like, VoiceThread, in fully online classes presented a new challenge. Logan created short online modules to introduce this software to fully online learners which then allowed students to try the software in fun and engaging icebreaker activities. These students, located across the country, were finally able to have discussions, provide peer feedback, and develop relationships with each other that would otherwise have gone missing in a static online learning environment. 
Creating online student-centered collaborative learning environments would not have been

possible for Peter without the professional knowledge and relationships built by Logan with professors and students. These trusting relationships allowed for synergistic course design opportunities between professors and a librarian that would otherwise have not occurred. The above reflection is a testament to what Doskatch (2003) writes about relationships when she says that they are "built on mutual trust and respect for each others' [sic] expertise and territory. This tenet should guide our practice" (p. 119). In this case, we do feel that Doskatch's tenet does guide Logan's practice and should be a model for future librarians to follow.

\section{Reflection 3: Librarian Relationships Support Scholarship}

All of the authors associate the library as a place of research. However, libraries are not always as accessible as they seem (McAfee, 2018). In our context, the websites and tools provided by the library are user-friendly. Faculty can go to the library website, request materials and conduct searches on their own. Unfortunately, while looking for research materials to support scholarship seems simple, locating relevant scholarship is sometimes confusing and stressful for those who have not been formally trained in conducting useful searches that yield meaningful results as Kate reflects below.

My memories of approaching the librarian throughout graduate school were generally negative. While there were very friendly librarians who hosted a multitude of teaching sessions on various resources, met with students and faculty to conduct searches, and were helpful when locating a book--they were never really individuals I relied on for real research support. For example, I have the distinct memory of making an appointment to support my ideas for an article about children's literature and female character representation that I wanted to write when I attended graduate school. I came prepared and excited with a backpack filled with a legal pad, multi-color pens, post-its, and my computer. I was delighted to finally locate and explore research with a librarian. I expected that the meeting would be productive, meaningful, and a wonderful start to new paper. Instead, I sat through a thirty-minute teaching session that did not seem to make much sense and the librarian did not send any helpful articles. Many of the articles the librarian selected were on children's literature in general. I was really interested in learning more about adolescent female character experiences in a specific sub-genre. On 
occasion, the librarian would show me something / thought was compelling. She would say, "This is something you can look at when you do your own search at home." The meeting felt rushed and pressure filled. Because I didn't really understand some of the search strategies used, I felt silly asking for help and clarification. -Kate, Reflection \#1

When Kate came to work at her current institution, she was surprised by the number of faculty members who raved about their librarian. After her first semester, she was also raving about him. His office door was always open, he met with faculty for one-on-one meetings, and he even found a way to meet via e-mail or other digital spaces. At this point, Kate had recruited two colleagues to co-author the article she started to consider in graduate school. Nervously, she approached Logan, the sting of those library meetings in her past still fresh.

I was really worried that he would think that I was completely inept. But, within a few minutes of conferencing and some side-by-side work, Logan produced a list of articles and proclaimed to my delight, "You're right, not many people are writing about this." I instantly felt encouraged and throughout the writing process continued to contact him with questions. My article was published within a year and contained a far more robust literature review than it would have should I have continued to conduct my research on my own because of the support from Logan. -Kate, Reflection \#2

Logan did not just help faculty, he also supported students with their research. He was embedded in Kate's class as someone to reach out to. When Kate instructed a research course, she was worried that her students would have the same negative experiences she did. To her surprise, many of the students already knew Logan and were very much at ease working with him. Many knew him from his work with them in their undergraduate courses.

When I first came to the institution, I was worried about asking for help with my research course. Two senior faculty members already embedded Logan in their courses. Throughout the semester he came to my class and gave search tool instruction, support for using library tools for annotated bibliographies, and showed students library templates for organizing their papers in a scholarly manner. Additionally, Logan created spaces and avenues for students to meet with him outside of class for research appointments. Interestingly, the search process helped students to naturally refine their topics into more focused and approachable research papers. Unlike my own experiences, my graduate students reached out to our librarian with 
ease and were confident asking for help. They knew that he had created avenues to support their research. He made it possible for them to learn the library research skills so many of us struggle with. -Kate, Reflection \#3

In this reflection the librarian's actions and past relationships with other members in the department helped shift Kate's view of librarians to be more positive. Additionally, the librarian also practiced what McAfee (2018) labels attunement: demonstrating “a genuine understanding for another person's position without judgment" (p. 249) as a way to help the students and faculty feel more comfortable.

\section{Analysis and Discussion}

Our stories of librarian collaboration reflect the range of academic instruction and librarian responsibilities- from bringing students to use the library and planning online courses, to writing for professional journals. While examining these unique reflections, several key ideas emerged that demonstrated our new understanding of the many affordances of working with our librarian in a liaison-based model of librarian collaboration. These key ideas are presented in Table 1 and include: 1 ) prior negative experiences with, or assumptions about librarians; 2) alleviation of assumptions and library anxiety through collaborative library partnerships; 3) establishment of trusting relationships through library collaboration; and 4) the development of shared trust.

\begin{tabular}{|l|l|}
\hline Key Idea & Elaboration \\
\hline $\begin{array}{l}\text { Negative assumptions } \\
\text { related to librarians }\end{array}$ & $\begin{array}{l}\text { Our prior negative experiences with librarians led us to believe that } \\
\text { librarians were not a useful resource. We were all surprised to learn that } \\
\text { a librarian could help us with each unique aspect of our profession, and } \\
\text { we then continued to be surprised as our relationship with our librarian } \\
\text { evolved to reach new levels of collaboration. }\end{array}$ \\
\hline $\begin{array}{l}\text { Quick alleviation of } \\
\text { assumptions and library } \\
\text { anxiety }\end{array}$ & $\begin{array}{l}\text { We were confronted with a librarian who broke our stereotypic beliefs. } \\
\text { Logan's enthusiasm, frequent communication, content knowledge of } \\
\text { education, pedagogical expertise, ability to find resources, and interest }\end{array}$ \\
\hline
\end{tabular}




\begin{tabular}{|l|l|}
\hline $\begin{array}{l}\text { Stronger trusting } \\
\text { relationships over time } \\
\text { librarian collaboration. }\end{array}$ & $\begin{array}{l}\text { As our relationships grew, we started to collaborate with Logan in new } \\
\text { ways that allowed for co-teaching and co-writing opportunities each } \\
\text { semester. Additionally, he started to co-publish papers and was treated } \\
\text { like an equal member of the department, rather than a resource or } \\
\text { search engine. }\end{array}$ \\
\hline $\begin{array}{l}\text { While our relationships and collaborative projects grew with Logan, } \\
\text { there were still some professors in our department who had not yet } \\
\text { collaborated with our librarian. During informal conversations with our } \\
\text { colleagues, we would often mention the strong benefits of our library } \\
\text { collaboration. Many of our fellow professors would mention their own } \\
\text { library anxiety or lack of knowledge about the resources a librarian } \\
\text { provided. Our long-term collaboration and trusting relationship with our } \\
\text { librarian slowly started to influence other department members, who } \\
\text { then invited him to assist with their in-class sessions, aid in } \\
\text { research/scholarship, and embed in their online courses. This resulted in } \\
\text { greater student support though student collaboration with Logan in all } \\
\text { phases of their program. }\end{array}$ \\
\hline
\end{tabular}

Table 1. Key Ideas in Collaboration

We hope the four key ideas that emerged from our stories help other libraries that use

generalist models to consider new pathways to build on collaboration and trust. As noted in the table

above, librarian and faculty partnerships and relationships can lend themselves to improved student experiences, improved faculty experiences, and a more cohesive college unit. As Education professors, our exposure to the library world has been limited to our experiences as undergraduates, graduate students, and as professors at our current institution.

In our experience, our college library shifted away from a liaison-based model in what appears to be the misuse of ideas from the field of "Library Sustainability" (Civallero \& Plaza, 2016). At the time, our library administration believed that a one-size-fits-all approach to assigning library instruction requests to classes would create a model that the library could sustain for years to come; however, 
relationships and the benefits that come from a liaison-based collaboration were dismantled. A more effective model of "Library Sustainability" is proposed by Caplan and Wong (2016) that specifically mentions ways to build sustainable teams. Specifically, Caplan and Wong suggest that libraries should not use a one-size-fits-all model of library instruction, but rather embrace the unique teaching backgrounds and styles of librarians and utilize them to create a diverse group that can collectively meet the needs of professors and students. Scheduling should be flexible and should be a shared responsibility of all librarians. This approach empowers librarians to teach library instruction the way that best matches their strengths as an educator, allows librarians to continue building relationships within their area of expertise where they serve as a department liaison, and also builds leadership capacity by placing librarians on a self-managed library instruction team.

\section{Conclusion}

This paper began as a result of our institution moving away from a liaison-based library support model to a functional specialist model where all librarians were considered interchangeable regardless of disciplinary expertise. This resulted in the decimation of a collaboration that had been in progress for over a decade. Reacting to our common loss, we came together to share our story and analyze the collaboration that we feel should be a model for other libraries. We urge library administrators to consider this type of liaison-based instruction model before shifting services for the sake of library sustainability. For instruction librarians, we offer the following questions to help guide their work with faculty:

1. How can I, in my college, work to establish relationships with colleagues outside of the physical library?

a. In what ways can I help reduce library anxiety among college professors?

b. How can I better inform professors of the services I can provide to support their students, course design, and scholarship? 
c. In what ways can increased communication and enthusiasm to collaborate shift perspectives of college librarians?

2. How can I resist a general model of library instruction?

3. How can I use my undergraduate or other degrees to forge relationships with specific disciplines?

4. What is a need that isn't being fulfilled by other individuals? How can I learn enough to be useful and competent in that arena?

We hope that our reflections, our analysis, and the peer-reviewed literature we have shared might help other librarians and library administrators consider ways to establish more conducive relationships that benefit all members of the college community.

Note: In our paper, we use the word faculty to refer to the various titles of individuals who are assigned the instructor of record in a course. We realize that at some institutions, including our own, librarians have faculty status. Additionally, our library has had a change in leadership after this article was written.

\section{References}

Adams, T., Holman Jones, S., and Ellis, C. (2015). Autoethnography: Understanding qualitative research. Oxford, UK : Oxford University Press.

Anderson, T.D., \& Fourie, I. (2015). Collaborative autoethnography as a way of seeing the experience of care giving as an information practice. Information Research, 20(1), 170-182.

Bury, S. (2011). Faculty attitudes, perceptions and experiences of information literacy: A study across multiple disciplines at York University, Canada. Journal of Information Literacy, 5(1). https://doi.org/10.11645/5.1.1513

Caplan, V. F., \& Wong, E. S. P. (2016). Diversity within unity: Jazzing up sustainable information literacy teams. Library Management, 37(6/7), 326-339. https://doi.org/10.1108/LM-05-2016-0039 
Cassidy, E. D., \& Hendrickson, K. E. (2013). Faculty-librarian micro-level collaboration in an online graduate history course. The Journal of Academic Librarianship, 39(6), 458-463. https://doi.org/10.1016/j.acalib.2013.08.018

Chang, H. (2008). Autoethnography as method. Walnut Creek, CA: Left Coast Press.

Civallero, E., \& Plaza, S. P. (2016). Libraries, sustainability and degrowth. Progressive Librarian 45, $20-$ 45.

Corrall, S. (2014). Designing libraries for research collaboration in the network world: An exploratory study. LIBER Quarterly, 24(1), 17.https://doi.org/10.18352/lq.9525

Deitering, A. (2017). Why autoethnography? In A. Deitering, R. A. Stoddart, \& R. Schroeder (Eds.), The self as subject: Autoethnographic research into identity, culture, and academic librarianship. Chicago, Illinois: ACRL.

Doskatsch, I. (2003). Perceptions and perplexities of the faculty-librarian partnership: An Australian perspective. Reference Services Review, 31(2), 111-121.

\section{https://doi.org/10.1108/00907320310476585}

Douglas, V. A., \& Rabinowitz, C. E. (2016). Examining the relationship between faculty-librarian collaboration and first-year students' information literacy abilities. College \& Research Libraries, 77(2), 144-163.https://doi.org/10.5860/crl.77.2.144

Ellis, C. (2019). Fighting back or moving on: An autoethnographic response to critics. International Review of Qualitative Research, 2(3), 371-378.

Ellis, C., Adams, T. E., \& Bochner, A. P. (2011). Autoethnography: An overview. Forum: Qualitative Social Research, 12(1). https://doi.org/10.17169/fqs-12.1.1589 
Fister, B. (2017). The warp and weft of Information Literacy: Changing contexts, enduring challenges. Journal of Information Literacy, 11(1), 68-79. https://doi.org/10.11645/11.1.2183

Geertz, C. (1973). Thick description: Toward an interpretive theory of culture. In The cultural geography reader (pp. 41-51). New York, NY: Routledge.

Guzik, E. (2013). Representing ourselves in information science research: A methodological essay on autoethnography. The Canadian Journal of Information and Library Science, 37(4), 267-283. https://doi.org/10.1353/ils.2013.0025

Hoodless, C., \& Pinfield, S. (2018). Subject vs. functional: Should subject librarians be replaced by functional specialists in academic libraries? Journal of Librarianship and Information Science, 50(4), 345-360. https://doi.org/10.1177/0961000616653647

Jiao, Q. G., \& Onwuegbuzie, A. J. (1999). Is library anxiety important? Library Review, 48(6), 278-282. https://doi.org/10.1108/00242539910283732

Johnson, C. M., McCord, S. K., \& Walter, S. (2003). Instructional outreach across the curriculum. The Reference Librarian, 39(82), 19-37. https://doi.org/10.1300/J120v39n82 03

Kelly, S. L. (2019). Faculty perceptions of librarian value: The moderating relationship between librarian contact, course goals, and students' research skills. The Journal of Academic Librarianship, 45(3), 228-233. https://doi.org/10.1016/j.acalib.2019.03.003

McAfee, E. L. (2018). Shame: The emotional basis of library anxiety. College \& Research Libraries, 79(2). https://doi.org/10.5860/crl.79.2.237

Mellon, C. A. (1986). Library anxiety: A grounded theory and its development. College \& Research Libraries, 47(2), 160-165. 
Meredith, W., \& Mussell, J. (2014). Amazed, appreciative, or ambivalent? Student and faculty perceptions of librarians embedded in online courses. Internet Reference Services Quarterly, 19(2), 89-112.https://doi.org/10.1080/10875301.2014.917756

Mezick, E. M. (2015). Relationship of library assessment to student retention. The Journal of Academic Librarianship, 41(1), 31-36.https://doi.org/10.1016/j.acalib.2014.10.011

Rath, L., \& Cimbricz, S. (2015). Collaborating around critical multiliteracies: A formula for success. Behavioral \& Social Sciences Librarian, 34(2), 47-54. https://doi.org/10.1080/01639269.2015.1042816

Rath, L., \& Wright, A. (2018). A pilot study of student perceptions of embedded library instruction. BRC Journal of Advances in Education, 3(1), 47-62.

Robinson, L. (1962). The role of the college librarian. Improving College and University Teaching, 10(2), 72-73.https://doi.org/10.1080/00193089.1962.10532153

SeyyedHosseini, S., Khosravi, A., \& Basirian Jahromi, R. (2014). Investigating the relationship between library anxiety and emotional intelligence. Webology, 11(2).

Wall, S. S. (2016). Toward a moderate autoethnography. International Journal of Qualitative Methods, 15(1), 1609406916674966. https://doi.org/10.1177/1609406916674966 
